\title{
NATIVE AND ALIEN DECAPODA SPECIES IN HUNGARY: DISTRIBUTION, STATUS, CONSERVATION IMPORTANCE
}

\author{
M. PUKY (1), J.D. REYNOLDS (2) and P. SCHÁD (3)
}

(1) Hungarian Danube Research Station of the Institute of Ecology and Botany, Hungarian Academy of Sciences, 2131 GÖD, Jávorka S. u. 14., Hungary.

E-Mail: h7949puk@ella.hu

(2) Department of Zoology, University of Dublin, Trinity College, Dublin 2, Ireland.

E-Mail: jrynolds@tcd.ie

(3) Varangy Akciócsoport Egyesület, 1013 Budapest, Pauler u. 19. Hungary.

E-Mail: schad@freemail.hu

Reçu le 17 décembre 2004

Accepté le 31 janvier 2005

Received December 17, 2004

Accepted January 31, 2005

\begin{abstract}
Three native (Astacus astacus, Astacus leptodactylus, Austropotamobius torrentium) and three alien (Orconectes limosus, Pacifastacus leniusculus, Eriocheir sinensis) Decapoda species have been found in Hungary so far. $A$. astacus is the most widespread Decapoda species in Hungary. A. leptodactylus might be considered as the least studied. The distribution of $A$. torrentium in Hungary is restricted to mountain streams with occasional data on its presence in the adjacent section of the River Danube. The indigenous species $A$. torrentium and, especially $A$. astacus, are declining while $A$. leptodactylus seems to have stable populations. The detection of alien species accelerated at the turn of the century: O. limosus was found at new sites, P. leniusculus was first recorded in the Gyöngyösstream near the Austrian border in 2000, E. sinensis in the main arm of the Danube at Budapest in November 2003. As there is a lack of information even on the commonest species, conservation-oriented mapping is necessary to follow the distribution changes of Decapoda in Hungary.
\end{abstract}

Key-words: crayfish, alien species, Hungary, distribution, conservation.

\section{LES DÉCAPODES INDIGÈNES ET EXOTIQUES EN HONGRIE : DISTRIBUTION, STATUT ET CONSERVATION}

\section{RÉSUMÉ}

Trois espèces indigènes de décapodes (Astacus astacus, Astacus leptodactylus, Austropotamobius torrentium) et trois espèces exotiques (Orconectes limosus, Pacifastacus leniusculus, Eriocheir sinensis) ont été trouvées en Hongrie. A. astacus est l'espèce la plus répandue et $A$. leptodactylus la moins étudiée. La distribution d'A. torrentium est limitée aux ruisseaux de montagne mais il existe quelques données occasionnelles sur sa présence dans la partie adjacente du Danube. Les espèces indigènes, $A$. torrentium et, particulièrement $A$. astacus, sont en déclin alors qu'A. leptodactylus présente des populations stables. La découverte des populations exotiques s'est amplifiée depuis la fin du siècle, $O$. limosus a été trouvée dans de nouveaux sites, $P$. leniusculus a été signalée 
pour la première fois dans le cours d'eau Gyöngyös - près de la frontière autrichienne en 2000 - et E. sinensis dans le bras principal du Danube à Budapest en novembre 2003. Étant donné qu'il y a un manque d'information même en ce qui concerne les espèces les plus communes, des cartographies sont nécessaires pour suivre les changements de distribution des décapodes en Hongrie avant toute orientation de conservation.

Mots-clés: écrevisses, espèces introduites, Hongrie, distribution, conservation.

\section{INTRODUCTION}

Decapoda are among the most threatened animal groups on Earth. Altogether 168 species are listed in the International Red Data Book (IUCN, 2003), while several species are also protected nationally or regionally. On the other hand, common species are commercially harvested and farmed. Several crayfish species have also turned out to be successful outside their natural distribution area. Mainly through deliberate introductions and from individuals escaped from farms, several alien species have successfully colonized new areas, even continents, and their spreading is cause for growing conservation concern.

In Hungary, three species are known to be natives: Astacus astacus Linnaeus, 1758, Astacus leptodactylus Eschscholz, 1823 and Austropotamobius torrentium (Schrank, 1803). There is a slight confusion in the literature as earlier works e.g. ENTZ (1909c) also listed Austropotamobius pallipes (Lereboullet, 1858) for the Hungarian Kingdom. However, as the present size of the country is only about $30 \%$ of what it used to be, all previous localities for that species are outside the present borders of the Hungarian Republic.

The conservation status of native Decapoda species is unusual in Hungary. Though both $A$. astacus and $A$. torrentium are listed in the International Red Data Book, only A. torrentium is protected nationally, while in several neighbouring countries both other species are given legal protection and listed in national Red Data Books (Table 1.).

Basic distribution data are also incomplete for Hungary, despite previous efforts such as those of the late Zoltán Thuránszky, whose 614 stream Decapoda distribution data from 1956-1960 were summarized by THURÁNSZKY and FORRÓ (1987). The initiative of CRAYNET to launch an all European crayfish distribution data collection and to evaluate the status of the species has had considerable influence on the development of this research area in Hungary and as a first step, the present paper summarizes the known distribution, status and conservation situation of Decapoda species in the country up to the time of the European data collection.

\section{MATERIAL AND METHODS}

Crayfish data were mainly collected through intensive literature survey including papers from 1909 to 2004 as no support was gained to carry out further fieldwork. Hungarian crayfish literature includes crayfish-oriented publications (e.g. ENTZ, 1909a, 1909b, 1909c), general Crustacea investigations of a more limited area (e.g. KONTSCHÁN, 2001) as well as the overview of several animal groups including Decapoda over larger regions (SALLAI and PUKY, 1998) and occasional crayfish observations made during the study of other groups or species (KOVÁCS and AMBRUS, 1998-99, 2001). Several crayfish specialists were interviewed and other experts (e.g. ichthyologists) were also contacted to incorporate their observations into the database. Some of them were reluctant to provide information because of conservation or other concerns but even so, the compiled database contains the observations of approximately 30 people. 
Table I

National or regional protection status of Decapoda species native to Hungary in neighbouring or otherwise related countries and by relevant organisations (COUNCIL OF EUROPE, 1998; HOLDICH and PÖCKL, 2005; HUDEC, 2001; IUCN, 2003; LEGE NR. 462/2001, 2001; SERBAKA, 1994; VYHLASKA 395/1992., 1992; ZIMMERMANN, 1993; 13/2001, 2001; 30/1994, 1994; 46/2004, 2004; 50/93, 1993; 76/1998, 1998; 82/2002, 2002).

\section{Tableau I}

Protection nationale ou régionale des espèces de décapodes indigènes en Hongrie, dans les pays adjacents ou pays connectés at par des organisations adéquates (COUNCIL OF EUROPE, 1998 ; HOLDICH and PÖCKL, 2005 ; HUDEC, 2001 ; IUCN, 1996 ; LEGE NR. 462/2001, 2001 ; SERBAKA, 1994 ; VYHLASKA 395/1992, 1992 ; ZIMMERMANN, 1993 ; 13/2001, 2001 ; 30/1994, 1994 ; 46/2004, 2004 ; 50/93, 1993 ; 76/1998, 1998 ; 82/2002, 2002).

\begin{tabular}{|l|c|c|c|}
\hline $\begin{array}{c}\text { Country, region or } \\
\text { organisation }\end{array}$ & $\begin{array}{c}\text { Austropotamobius } \\
\text { torrentium }\end{array}$ & Astacus astacus & $\begin{array}{c}\text { Astacus } \\
\text { leptodactylus }\end{array}$ \\
\hline Croatia & $\mathbf{X}$ & $\mathbf{X}$ & $\mathbf{X}$ \\
\hline Czech Republic & $\mathbf{X}$ & $\mathbf{X}$ & \\
\hline European Union & $\mathbf{X}$ & $\mathbf{X}$ & \\
\hline Hungary & $\mathbf{X}$ & $\mathbf{X}$ & \\
\hline IUCN & $\mathbf{X}$ & & \\
\hline $\begin{array}{l}\text { State of Vienna, } \\
\text { State of Tyrol, } \\
\text { Austria }\end{array}$ & $\mathbf{X}$ & $\mathbf{X}$ & \\
\hline Romania & $\mathbf{X}$ & $\mathbf{X}$ & \\
\hline $\begin{array}{l}\text { Serbia and } \\
\text { Montenegro }\end{array}$ & $\mathbf{X}$ & $\mathbf{X}$ & $\mathbf{X}$ \\
\hline Slovenia & $\mathbf{X}$ & $\mathbf{X}$ & \\
\hline Slovakia & & & \\
\hline Ukraine & & & \\
\hline Thüringen & & & \\
\hline
\end{tabular}

Field data were mainly collected by searching possible crayfish habitats, such as mountain streams by turning stones and checking holes during the day and torching during the night. Traps of different design baited with e.g. pork liver were applied in several studies. Crayfish were also caught by electrofishing during ichthyological surveys. The occasional finding of dead crayfish on the banks of running waters or lake shores and results gained by autumn fishing, when the water of fishponds is completely released, were also taken into consideration.

To provide reliable data, doubtful records were not included in the compiled database. These sites should be checked in the future, as it is possible they might provide valuable additional information. 


\section{RESULTS AND DISCUSSION}

Data are presented here in a graphical format, which shows the distribution area of the species in $50 \mathrm{~km} \times 50 \mathrm{~km}$ UTM square units. From among 58 such squares covering Hungary, crayfish data are available from 41 (70,7\%).

\section{Native crayfish distribution}

Three native decapod species (A. astacus, A. leptodactylus, A. torrentium) have been found in Hungary so far. Taking into consideration data going back nearly to a hundred years (ENTZ, 1909a, 1909b, 1909c), A. astacus is the most widespread species. It is present in $90.2 \%$ of all squares containing data. However, its decline has been attributed by several authors to the drying out of streams, pollution and unknown factors (KISZELY, 1992, 1994; PINTÉR and THURÁNSZKY, 1983). As the distribution map shows (Figure 1.), it is more common in the western and northern part of the country, where at certain sites it can be abundant, but it is also present e.g. in the River Tisza. It inhabits both running and standing waters.

Astacus leptodactylus data were collected from sixteen $50 \mathrm{~km} \times 50 \mathrm{~km}$ UTM squares: $39 \%$ of all squares containing data. It is the least studied Decapoda species in Hungary. As the distribution map demonstrates (Figure 2.), there are large gaps even in the known distribution area of this species; which is most usually present in lowland waters and fishponds. It used to be abundant in Lake Balaton, but the introduction of the eel (Anguilla

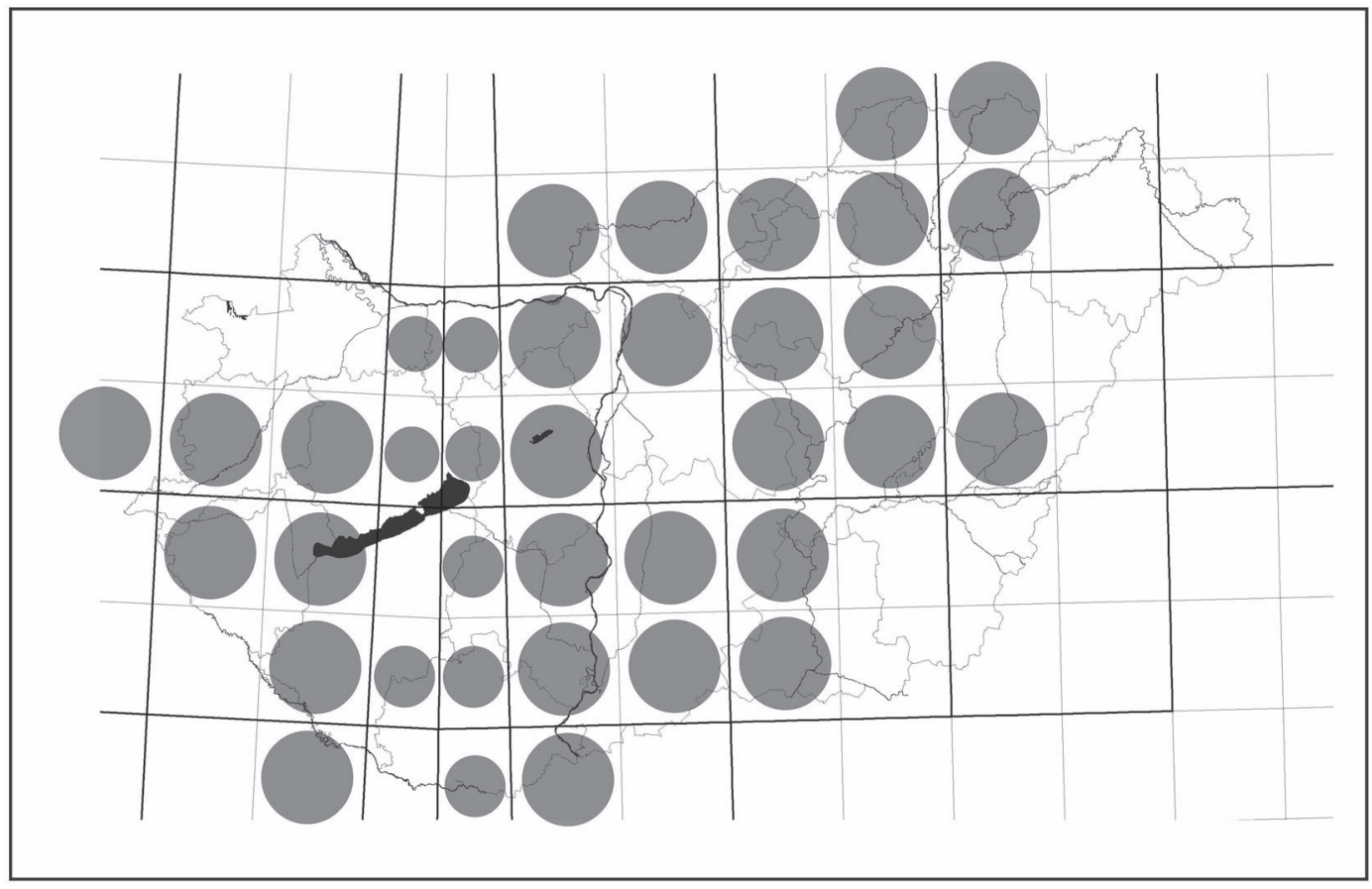

Figure 1

$50 \mathrm{~km} \times 50 \mathrm{~km}$ UTM distribution of Astacus astacus in Hungary (the edge of the squares represent $50 \mathrm{~km}$ ). Empty square: no data; solid circle: data available.

\section{Figure 1}

$50 \mathrm{~km} \times 50 \mathrm{~km}$ UTM distribution d'Astacus astacus en Hongrie (la taille des carrés représentent $50 \mathrm{~km}$ ). Carrés vides : aucune donnée ; Cercles pleins : données disponibles. 


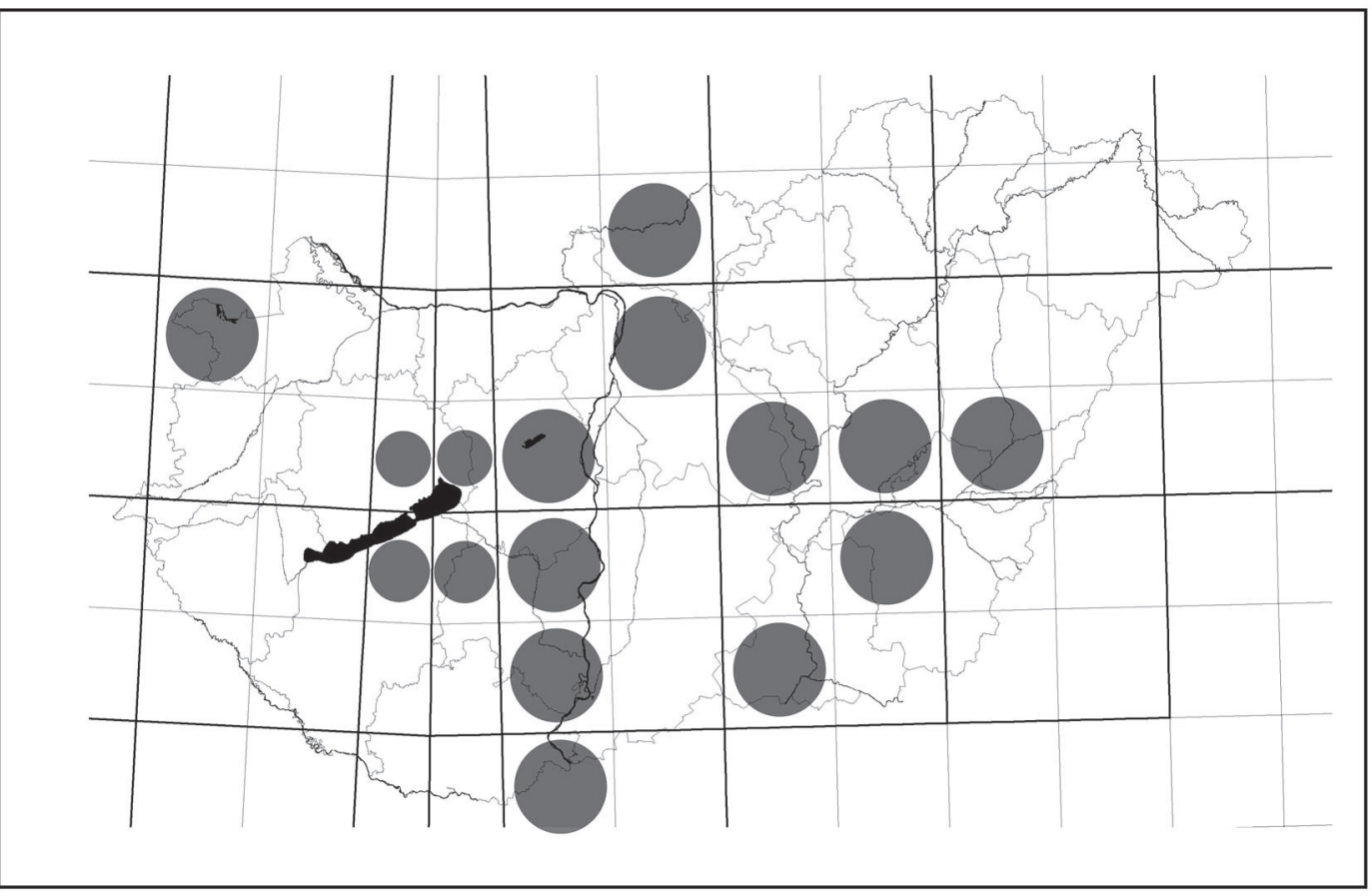

\section{Figure 2}

$50 \mathrm{~km} \times 50 \mathrm{~km}$ UTM distribution of Astacus leptodactylus in Hungary (the edge of the squares represent $50 \mathrm{~km}$ ). Empty square: no data; solid circle: data available.

\section{Figure 2}

$50 \mathrm{~km} \times 50 \mathrm{~km}$ UTM distribution d'Astacus leptodactylus en Hongrie (la taille des carrés représentent $50 \mathrm{~km}$ ). Carrés vides : aucune donnée ; Cercles pleins : données disponibles.

anguilla) caused its extinction in the 1960s (KISZELY, 1994), similarly to the lower stretch of the River Zala, which flows into the lake from the west (PINTÉR and THURÁNSZKY, 1983). Though it is a commercially utilised species in other parts of its range, both where it occurs naturally such as Turkey (HARLIOGLU, 2004) or where it is introduced such as the U.K. (HARLIOGLU and HOLDICH, 2001), there has been little exploitation and no farming or specific research carried out on this species in Hungary.

The distribution of $A$. torrentium is local in Hungary (Figure 3.). It is restricted to mountain streams with occasional reports of its presence in adjacent sections of the River Danube (ENDES, 1989). Populations in the western part of the country discovered in the last decade (ILLÉS, 2004a) are restricted to several small, first or second order streams in one mountain range. Unlike Croatia and Switzerland, no mixed populations of $A$. torrentium and $A$. astacus (MAGUIRE and GOTTSTEIN-MATOCEC, 2004) or $A$. torrentium, $A$. astacus and $A$. leptodactylus are known to be found in Hungary (STUCKI and ROMER, 2001). The stone crayfish may be regarded as the best-studied species in Hungary as the Young Naturalist Club of the Hungarian Natural History Museum and the Hungarian Biological Society collected data on this species since more than one decade now (BIRKENHEUER, 1992; ROGOVSZKY, 1995; ROGOVSZKY, 2004). This also resulted in the development of an educational material and an initiative for crayfish monitoring. Detailed analyses of two populations from the Danube - Ipoly National Park are expected to be published soon (ROGOVSZKY, 2004). 


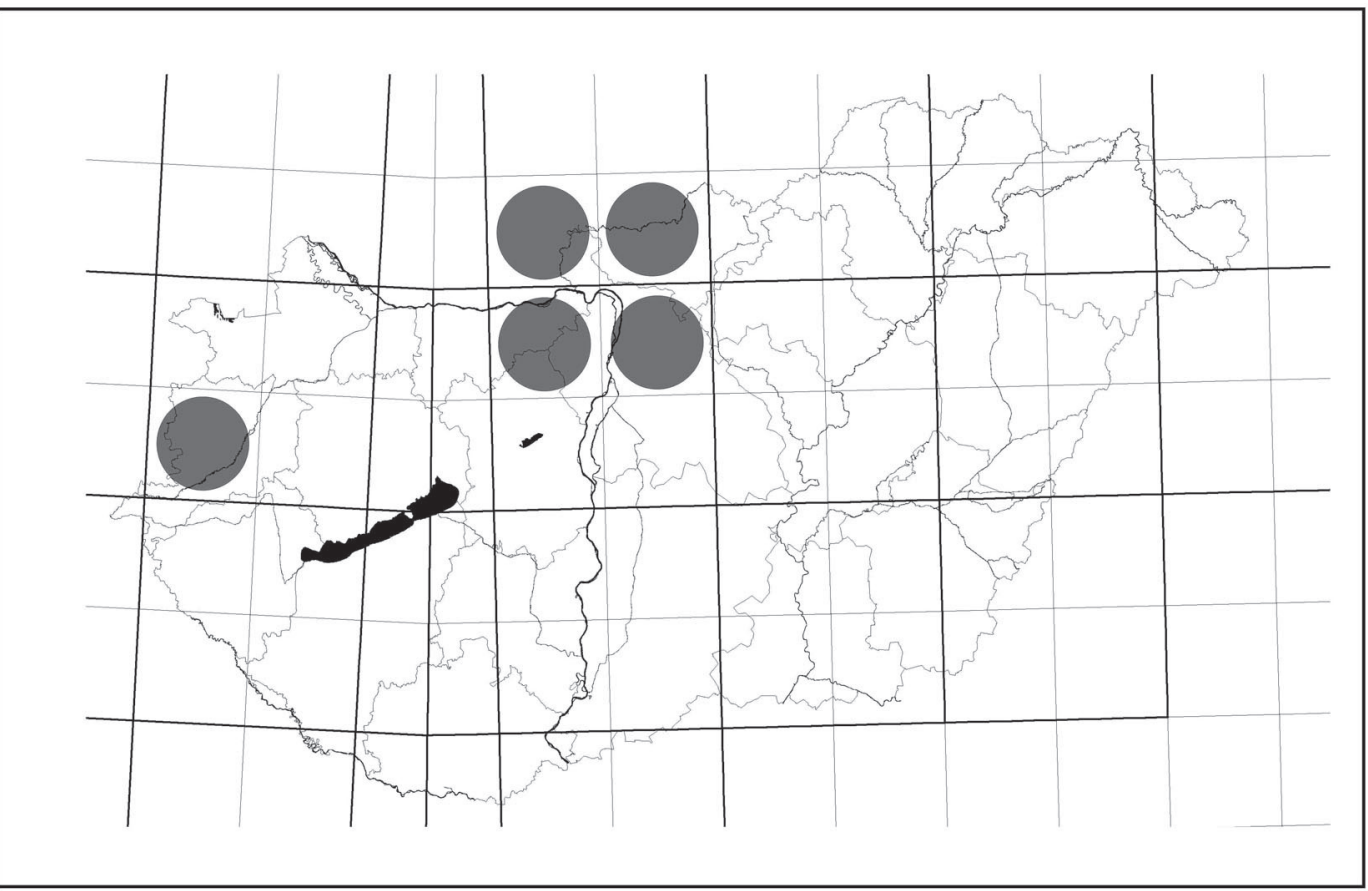

\section{Figure 3}

$50 \mathrm{~km} \times 50 \mathrm{~km}$ UTM distribution of Austropotamobius torrentium in Hungary (the edge of the squares represent $50 \mathrm{~km}$ ). Empty square: no data; solid circle: data available.

\section{Figure 3}

$50 \mathrm{~km} \times 50 \mathrm{~km}$ UTM distribution d'Austropotamobius torrentium en Hongrie (la taille des carrés représentent $50 \mathrm{~km}$ ). Carrés vides : aucune donnée; Cercles pleins : données disponibles.

\section{Alien crayfish distribution}

The detection of alien species accelerated at the turn of the century in Hungary. Orconectes limosus (Rafinesque, 1817) was found at new sites, Pacifastacus leniusculus (Dana, 1852) was first recorded in 2000, Eriocheir sinensis (Milne Edwards, 1854) in November 2003. Orconectes limosus, a North American crayfish, has become predominant in parts of Europe such as the Netherlands (ADEMA, 1989), northeastern Germany and northwestern Poland (SCHULZ and SMIETANA, 2001) and can become the commonest prey of fish such as the wels (catfish) or other piscivorous fish in certain life stages (CZARNECKI, ANDRZEJEWSKI and MASTYNSKI, 2003; HAERTEL, BAADE and ECKMANN, 2002). It was introduced to Hungary from Germany in the late 1950s for farming (THURÁNSZKY, 1960). Until 1985, however, it was not detected in natural Hungarian waters. THURÁNSZKY and FORRÓ (1987) first recorded this species in the wild in a large secondary branch of the River Danube. Since then, abundant and spreading populations have been found in other side arms and tributaries of the river (Figure 4.) such as the Szõdrákos-stream and the Sió canal (NESEMANN, PÖCKL and WITTMANN, 1995; PUKY, 2000, 2004). At present no farming is maintained and no specific research is oriented towards this species.

Pacifastacus leniusculus is native to northwestern North America. It has been widely introduced to California and Europe and has raised concerns because of its impacts not only on native crayfishes (HOLDICH, 1999) but also fish (GRIFFITHS, COLLEN and 


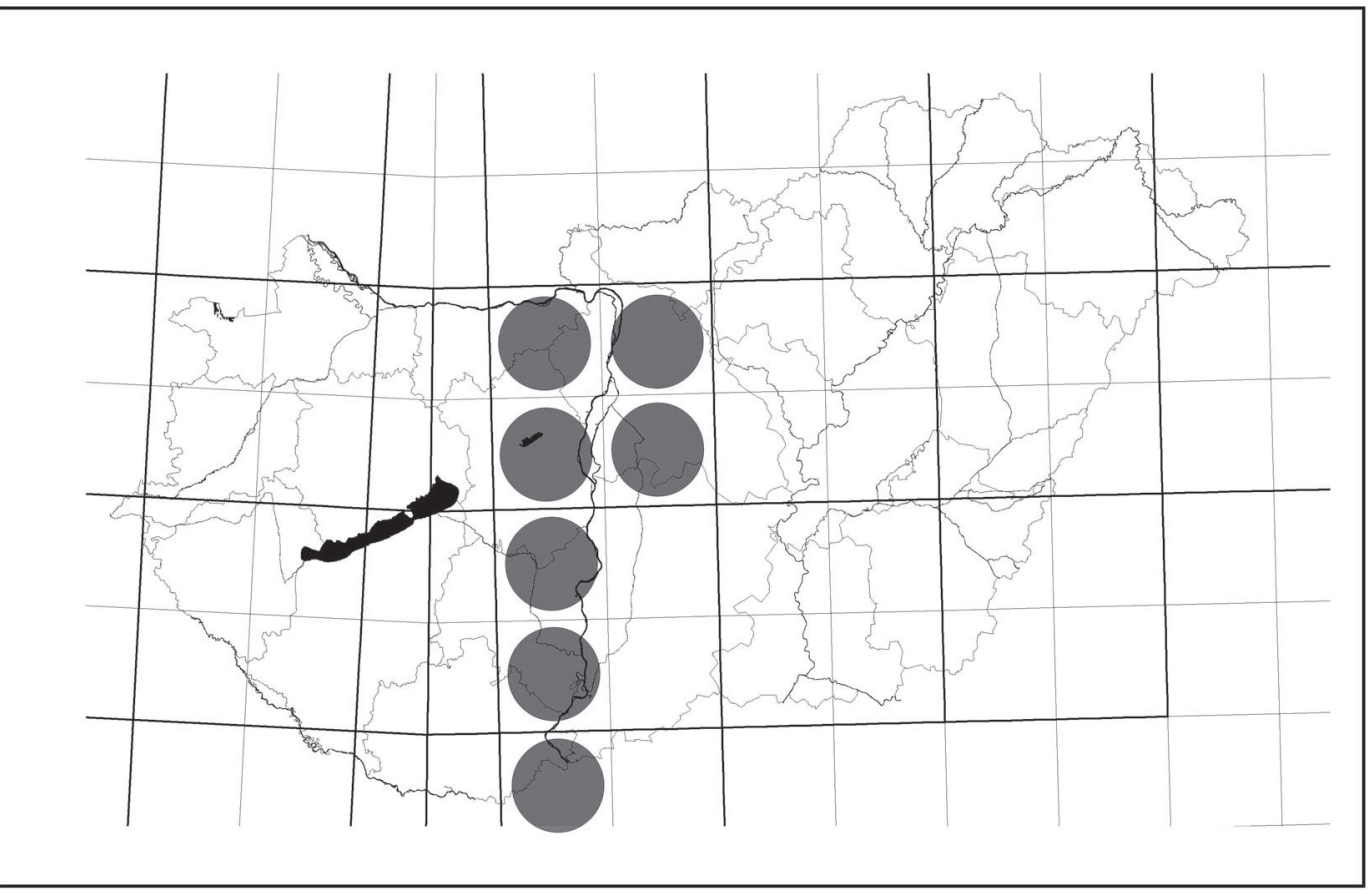

\section{Figure 4}

$50 \mathrm{~km} \times 50 \mathrm{~km}$ UTM distribution of Orconectes limosus in Hungary (the edge of the squares represent $50 \mathrm{~km}$ ). Empty square: no data; solid circle: data available.

\section{Figure 4}

50 km $\times 50$ km UTM distribution d'Orconectes limosus en Hongrie (la taille des carrés représentent $50 \mathrm{~km}$ ). Carrés vides: aucune donnée; Cercles pleins : données disponibles.

ARMSTRONG, 2004; GUAN and WILES, 1997) and amphibians (AXELSSON et al, 1997). It was first recorded in Hungary in 2000 (remains of a dead individual were found in the Gyöngyös stream at Kõszeg) and the first live specimen was caught in the following year several kilometres away (ILLÉS, 2002, 2004b). Since then intensive studies of a $46 \mathrm{~km}$ stretch (ILLÉS, 2004b) revealed abundant populations along an $18 \mathrm{~km}$ section (Figure 5.). $P$. leniusculus was recorded to be able to move $120 \mathrm{~m}$ in a day suggesting significant dispersal ability (LIGHT, 2003). As larger crayfish move greater distances and are more likely to move downstream, it is expected to spread further in the catchment of the River Rába.

Eriocheir sinensis is the most recently found Decapoda species in Hungary. It is a commercially important catadromous species native to Eastern Asia. It declined there over large areas due to overfishing, water pollution and dam construction, cutting off migration passages in China since 1982 (JIN, LI and XIE, 2001). In North America and Europe, however, it is a successful invasive species. Its European range stretches from Portugal and the U.K. to Finland and Russia (CABRAL and COSTA, 1999; CLARK et al., 1998; HAAHTELA, 1963; INGLE, 1986). Unlike the other two alien species, E. sinensis has also been recorded in terrestrial habitats during its migration, e.g. as road kills (RETTIG, 2000). Already known in the Austrian and Serbian Danube (PAUNOVIC et al., 2004; RABITCH and SCHIEMER, 2003), its presence has been confirmed in the River Danube in Hungary (Figure 6.). Danubian fishermen spoke about occasional catches of crab-like animals since the middle of the 1990s in Hungary. The first live animal was collected in the main arm of the Danube, south of Budapest in November 2003 (B. CSÁNYI, G. CSÖRGITS, A. NEMES, 


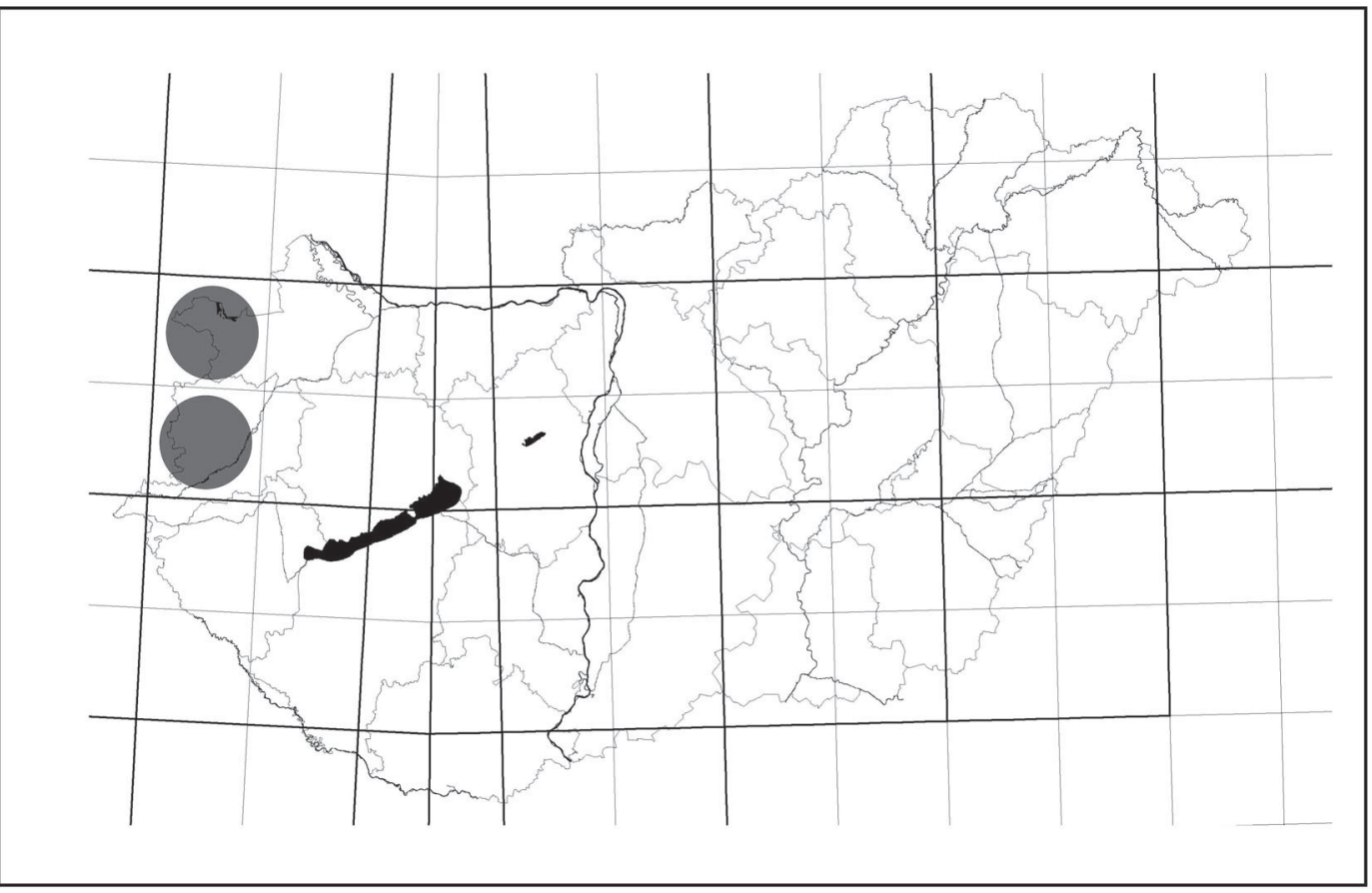

\section{Figure 5}

$50 \mathrm{~km} \times 50 \mathrm{~km}$ UTM distribution of Pacifastacus leniusculus in Hungary (the edge of the squares represent $50 \mathrm{~km}$ ). Empty square: no data; solid circle: data available.

\section{Figure 5}

50 km $\times 50$ km UTM distribution de Pacifastacus leniusculus en Hongrie (la taille des carrés représentent $50 \mathrm{~km}$ ). Carrés vides : aucune donnée ; Cercles pleins : données disponibles.

pers. comm.). As during the peak period of two previous invasions in Europe, this species expanded its range by 562 and $380 \mathrm{~km}$ per year (HERBORG et al., 2003), and it was also found in the Black Sea (GOMUI et al., 2002), where the Danube flows in, it has theoretically a potential to colonise the whole river. Where the Chinese mitten crab became invasive in Europe or North America, the species greatly affected biodiversity, commercial fishing, angling, river bank erosion, especially in banks with steep gradient along sections with fluctuations in water level, e.g. below dams used for peak electricity production (CABRAL and COSTA, 1999; CLARK et al, 1998; HERBORG et al., 2003; INGLE, 1986). At present, no research programs exist on this species in Hungary.

\section{Crayfish farming, introduction, re-introduction}

Crayfish harvesting has a long tradition in Hungary. $16^{\text {th }}$ and $17^{\text {th }}$ century publications reported cartloads of crayfish (probably nearly exclusively $A$. astacus) being taken to Vienna for culinary purposes (summarized by OLÁH, 1763; ULISSES, 1642; in ENTZ, 1909a). Although occasional collections of other species such as O. limosus are known, $A$. astacus has been and is the most important crayfish species in Hungary from this respect and its stock has been exploited and exported until the second half of the $20^{\text {th }}$ century, even if the great crayfish plague decimated its number nationally. To improve the situation re-introductions started in 1898. Up to 1914 approximately 1,314,000 specimens were released, usually 1,000-2,000 individuals per kilometer of stream. In the years 1939-1942 and 1958-59 approximately 10,000 and 11,814 animals, respectively, 


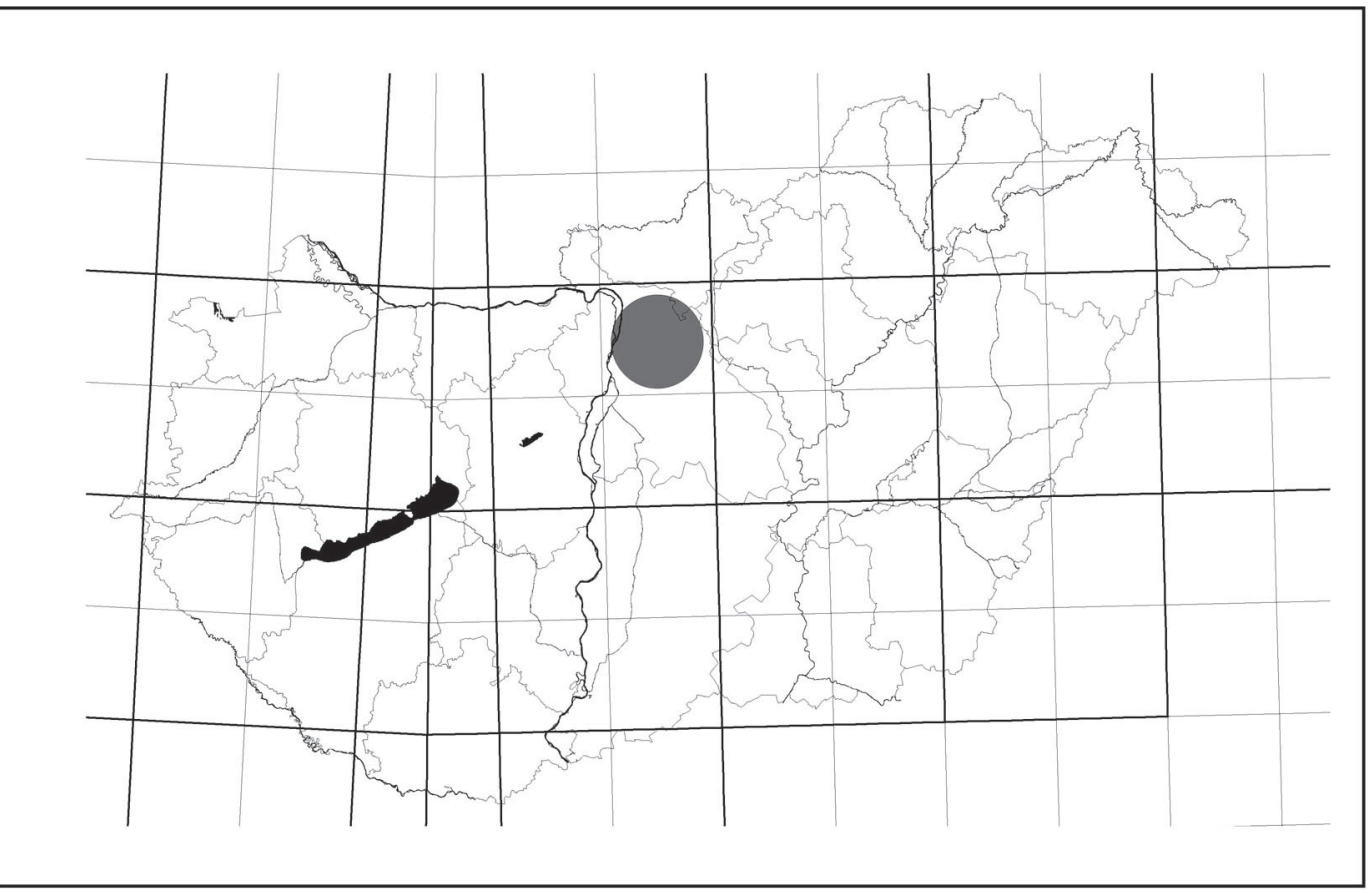

\section{Figure 6}

$50 \mathrm{~km} \times 50 \mathrm{~km}$ UTM distribution of Eriocheir sinensis in Hungary (the edge of the squares represent $50 \mathrm{~km}$ ). Empty square: no data; solid circle: data available.

\section{Figure 6}

$50 \mathrm{~km} \times 50 \mathrm{~km}$ UTM distribution d'Eriocheir sinensis en Hongrie (la taille des carrés représentent $50 \mathrm{~km}$ ). Carrés vides: aucune donnée; Cercles pleins : données disponibles.

were introduced into different waters (THURÁNSZKY, 1960). In the second half of the $20^{\text {th }}$ century crayfish exports gradually decreased. In 1956, a total mass of 13 tons of the noble crayfish was exported from Hungary but since then it dropped to 1 ton by 1980 . Crayfish plague, pollution and water regulation was suggested as the main causes for this decline (PINTÉR and THURÁNSZKY, 1983). Harvesting from natural waters as well as farming was tried repeatedly later, in the $20^{\text {th }}$ century, also with introduced $O$. limosus populations (PINTÉR and THURÁNSZKY, 1983; THURÁNSZKY, 1960). To exploit crayfish even more efficiently farming and further re-introduction was also suggested several times (THURÁNSZKY, 1960; PINTÉR and THURÁNSZKY, 1983). Even today, local people collect noble crayfish as a delicacy, e.g. in the Zala County. Since the 1980s, however, the aim of crayfish reintroduction often shifted towards a conservation purpose. At the early 1990s a re-introduction and breeding program was started in the Balaton Uplands National Park (KISZELY, 1992, 1994) where individuals collected from nearby localities are introduced into appropriate, mainly lotic, habitats.

\section{Recent mortalities, disease}

Crayfish mortality has been recorded at several sites in recent years (e.g. along the Sió canal) but with only one exception no detailed analyses were made. ROGOVSZKY $(1995,2004)$ described and followed the fate of an A. torrentium population in the Pilis Mountains. In 1994, several years after the regional crayfish study had started, an organic pollution spill killed the whole population from the Apátkúti-stream. In spite of regular site 
visits by the same author, no re-colonization has been detected ever since, probably also due to further pollution events. Crayfish plague should be, or at least should have been, present in Hungary as German populations were suspected to have got the disease from animals imported from this country (M. KELLER, pers. comm.). No national publication, however, is available on this topic. At several sites chytromyosis has been suspected and there are plans for such investigations (P. KISZELY, pers. com.) using international help.

\section{Existing legislation, threats and conservation measures, crayfish conservation sites}

At present only one species, $A$. torrentium is protected by national legislation in Hungary. Its nature conservation value, i.e. the fine for killing or harming one individual, is 10,000 HUF (approximately $40 €$ ). Crayfish are present in protected areas (NATURA 2000 sites, national parks or other protected areas) in Hungary but no crayfish reserve has been designated so far. The main threats for native Decapoda species are summarized in Table 2. Habitat alteration/disappearance and pollution seem to be the most important factors causing decline, but the effects of alien species and disease could not be evaluated as information is missing in this field. This is also a main threat in itself. As the presence of native species as well as the colonization of alien species depends on multiple factors, such as water chemistry (see e.g. RALLO and GARCIA-ARBERAS, 2002 for $P$. leniusculus and $A$. pallipes), a thorough analysis of interactions is also necessary to adequately describe threats and compensate their effects. The newly discovered A. torrentium populations, for example, which are stable now (ILLÉS, 2004a), may be threatened in the future if $P$. leniusculus enters the upstream part of the Gyöngyös stream either by natural colonization or by deliberate introduction. Even if it moves more slowly upstream than downstream (BUBB, THOM and LUCAS, 2004), the signal crayfish, growing to a larger body size with higher reproductive rates, can be dominant in aggressive interactions and thus replace the indigenous species. If infected by the crayfish fungus, Aphanomyces astaci SCHIKORA, 1903, it can transmit the disease to non-resistant A. torrentium individuals, which, under laboratory conditions, die as fast as in two weeks (VORBURGER

\section{Table 2}

Relative importance of different threats to native Decapoda species in Hungary.

Tableau 2

Importance relative des différentes menaces affectant les espèces de Décapodes indigènes en Hongrie.

\begin{tabular}{|l|l|}
\hline \multicolumn{1}{|c|}{ Threat } & \multicolumn{1}{c|}{ Importance } \\
\hline $\begin{array}{l}\text { Habitat alteration and disappearance, } \\
\text { water regulation }\end{array}$ & A most important factor. \\
\hline Pollution & A most important factor. \\
\hline Lack of information & An important threat. \\
\hline Alien Decapoda species & Especially for A. astacus? \\
\hline Disease & Important? \\
\hline Isolation & $\begin{array}{l}\text { Especially at } A \text {. torrentium and } \text { A. astacus } \\
\text { in small streams. }\end{array}$ \\
\hline Collection & Local importance. \\
\hline Drying out of habitats & Locally important. \\
\hline Eutrophication & Secondary effects. \\
\hline
\end{tabular}




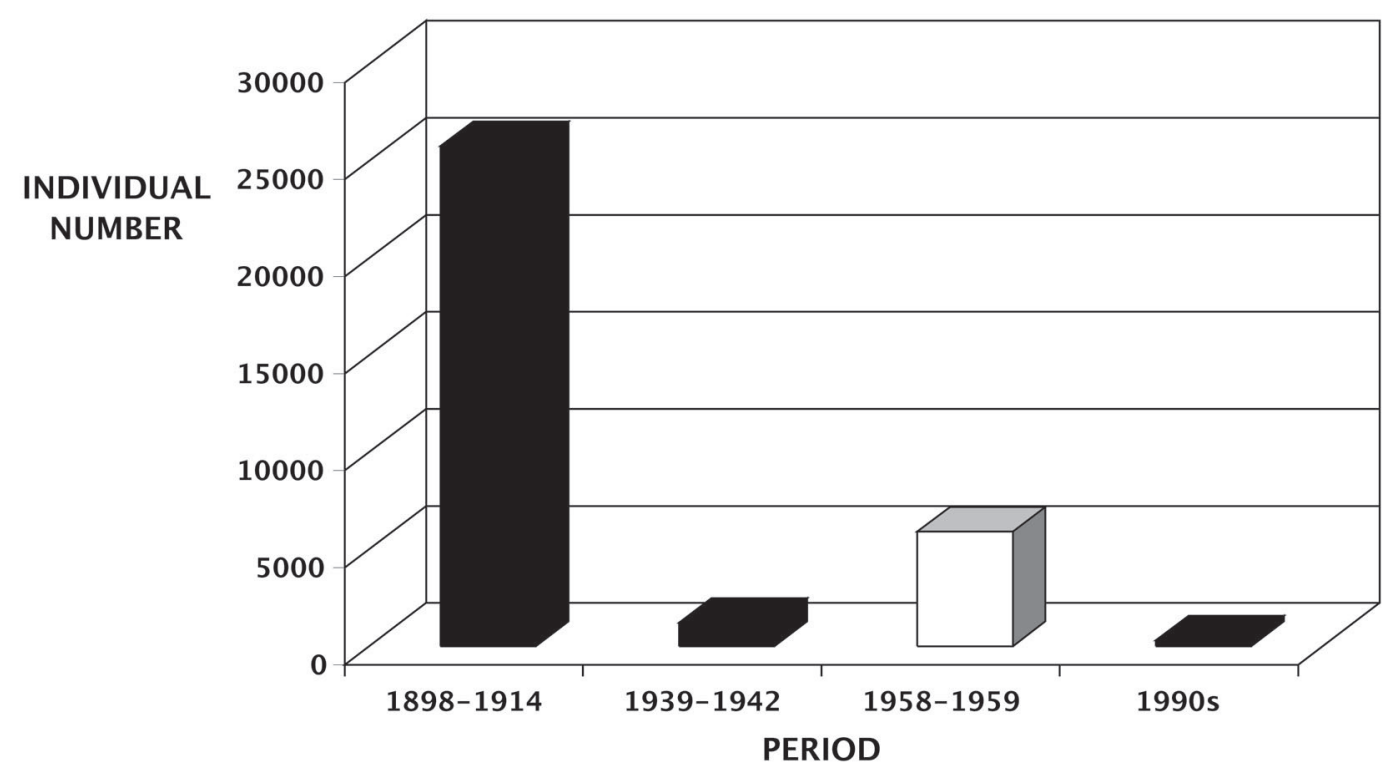

Figure 7

Average annual crayfish (re)introduction intensity in Hungary according to THURÁNSZKY, (1960) and KISZELY $(1992,1994)$ (Note changes in the size of the country have been taken into consideration). Solid bar: Astacus astacus; empty bar: Orconectes limosus.

\section{Figure 7}

Intensité de (ré)introduction annuelle d'écrevisses en Hongrie selon THURÁNSZKY, (1960) et KISZELY $(1992,1994)$ (il est à noter le changement de taille du pays à prendre en considération). Barres pleines: Astacus astacus; barres vides: Orconectes limosus.

and RIBI, 1999). Other mechanisms, such as reproductive interference, can also play a role in such replacement processes even if the alien species is not infected by disease (WESTMAN, SAVOLAINEN and JULKUNEN, 2002).

The re-introduction and breeding program in the Balaton Uplands National Park (KISZELY, 1992, 1994) where individuals collected from nearby localities are introduced to appropriate localities nearby, is a promising approach to counter-balance declines due to factors such as temporary drying out of streams in the Balaton Uplands. Figure 7. demonstrates that it is a small scale operation at the moment, especially in comparison with previous projects. In the future this activity should be more intensive and become an important element of a national crayfish conservation plan. As from the four Decapoda species known from the region at the time of writing, the population level monitoring of three (A. astacus, A.torrentium, O. limosus) and all four species (also including A. leptodactylus) was suggested to be included in the minimum and optimal programme of the national biodiversity monitoring plan (FORRÓ, 1997), respectively, there is a chance that crayfish-oriented research, monitoring and education will be more common in the future.

\section{CONCLUSION}

Crayfish are the largest macroinvertebrates in Hungarian waters. They have various effects on aquatic communities. They affect habitats, e.g. by bedform alterations in 
riffles (STATZNER, PELTRET and TOMANOVA, 2003), enhance benthic algal production through physical activity, reduce growth and survival of bryozoan communities, reduce macroinvertebrate taxon richness (CALLAGHAN and KARLSON, 2002; STENROTH and NYSTRÖM, 2003), play an important role in the food web, e.g. by becoming the dominant food source of the European mink (Mustela lutreola) or the strictly protected otter (Lutra lutra) in summer under certain conditions (LANSZKY and MOLNÁR, 2003; SIDOROVICH et al., 2002), and even their presence proved to have significant effect on prey organisms such as accelerating the hatching of amphibian eggs (SAENZ et al., 2003). In addition, they are also used commercially and their biomarker response can be used to detect contaminant release (TRIEBSKORN et al., 2002). In spite of all this, crayfish have not been in the focus of research in Hungary in the twentieth century. However, there have been several people, such as the late Géza ENTZ and Zoltán THURÁNSZKY, who collected valuable records in the past that serve as important resources even today. After some decades of less intensive data collection, with a clear shift from a commercial to a conservation approach, interest in crayfish is again growing in Hungary. As the main investigators include dedicated teachers, there is a realistic hope that this interest will also be passed on effectively to the next generations that will also help to maintain the longterm survival of indigenous species and support crayfish research in general. To increase knowledge on crayfish species in Hungary, further initiatives similar to that which has been launched by the Göncöl Association, including the publication of a crayfish survey manual with detailed general, conservational and methodological information (HARSÁNYI and ROGOVSZKY, 1996), are needed to foster astacological education and research in Hungary.

\section{ACKNOWLEDGEMENTS}

The authors thank Dr. Sándor ANDRIKOVICS, Dr. Árpád BERCZIK, Dr. István BANCSI, Gábor CSÖRGITS, Dr. Béla CSÁNYI, Tibor ERÕS, Dorottya GÉMESI, Péter ILLÉS, Dr. Max KELLER, Pál KISZELY, Dr. György KRISKA, Attila NEMES, Dr. János NOSEK, Dr. Nándor OERTEL, Zoltán POLLER, Zoltán ROGOVSZKY, Zoltán SALLAI and Balázs TÓTH for providing additional information to the data collection, Hana CHOBOTSKA, Katarina DENAC, Nevena JELISIC, Dr. Pável KOZÁK, Dr. Andreja LUCIC, Dr. Manfred PÖCKL and Cristina SANDU for helping in the compilation of legal data presented in Table 1. and Dr. Catherine SOUTY-GROSSET for the French translation.

\section{REFERENCES}

ADEMA J.P.H.M., 1989. De verspreiding van rivierkreeften in Nederland. Niewsbrief European Invertebrate Survey-Nederland, 19, 3-10.

AXELSSON E., NYSTRÖM P., SIDENMARK J., BRÖNMARK C., 1997. Crayfish predation on amphibian eggs and larvae. Amphibia-Reptilia, 18, 217-228.

BIRKENHEUER V., 1992. A kövirák megfigyelése az Apátkúti-patakban. Természet Világa, $123,45-46$.

BUBB D.H., THOM T.J., LUCAS M.C., 2004. Movement and dispersal of the invasive signal crayfish Pacifastacus leniusculus in upland rivers. Freshwater Biology, 49, 357-368.

CABRAL H.N., COSTA M.J., 1999. On the occurrence of the Chinese mitten crab, Eriocheir sinensis, in Portugal (Decapoda: Brachyura). Crustaceana, 72, 55-58.

CALLAGHAN T.P., KARLSON R.H., 2002. Summer dormancy as a refuge from mortality in the freshwater bryozoan Plumatella emarginata. Oecologia, 132, 51-59. 
CLARK P.F., RAINBOW P.S., ROBBINS R.S., SMITH B., YEOMANS W.E., THOMAS M., DOBSON G., 1998. The alien Chinese mitten crab Eriocheir sinensis (Crustacea: Decapoda: Brachyura) in the Thames catchment. Journal of the Marine Biological Association United Kingdom, 78, 1215-1221.

COUNCIL OF EUROPE, 1998. Convention on the conservation of European wildlife and natural habitats. Council of Europe, Strasbourg, $25 \mathrm{p}$.

CZARNECKI M., ANDRZEJEWSKI W., MASTYNSKI J., 2003. The feeding selectivity of wels (Silurus glanis L.) in Lake Goreckie. Archiwum Rybactwa Polskiego, 11, 141147.

ENDES M., 1989. Kövi rák (Astacus torrentium) a Dunában. Calandrella, 3, 71.

ENTZ G., 1909a. A magyarországi folyami rákokról (Elsõ közlemény). Állattani Közlemények, 8, 37-52.

ENTZ G., 1909b. A magyarországi folyami rákokról (Második közlemény). Állattani Közlemények, 8, 97-110.

ENTZ G., 1909c. A magyarországi folyami rákokról (Harmadik közlemény). Állattani Közlemények, 8, 149-163.

FORRÓ L., 1997. Rákok - Crustacea. In: FORRÓ, L. (ed), Nemzeti Biodiverzitás-monitorozó Rendszer. V. Rákok, szitakötõk és egyenesszárnyúak. Hungarian Natural History Museum, Budapest, 15-32.

GOMUI M.T., ALEKSANDROV B., SHADRIN N., ZAITSEV T.Y., 2002. The Black Sea - a recipient, donor and transit area for alien species. In: LEPPAEKOSKI, E., GOLLASCH, S., OLENIN, S. (Eds) Invasive aquatic species of Europe. Distribution, impacts and management. Kluwer Academic Publishers, 341-350.

GRIFFITHS S.W., COLLEN P., ARMSTRONG J.D., 2004. Competition for shelter among over-wintering signal crayfish and juvenile Atlantic salmon. Journal of Fish Biology, 65, 436-447.

GUAN R.Z., WILES P.R., 1997. Ecological impact of introduced crayfish on benthic fishes in a British lowland river. Conservation Biology, 11, 641-647.

HAAHTELA I., 1963. Some observations and remarks of the occurrence of the mitten crab (Eriocheir sinensis Milne Edwards (Crustacea: Decapoda) in Finland. Aquilo, 1, 916.

HAERTEL S.S., BAADE U., ECKMANN R., 2002. No general percid dominance at mesotrophic lake conditions: Insights from the quantification of predator-prey interactions. Limnologica, 32, 1-13.

HARLIOGLU M.M., 2004. The present situation of freshwater crayfish, Astacus leptodactylus (Eschscholtz, 1823) in Turkey. Aquaculture, 230, 181-187.

HARLIOGLU M.M., HOLDICH D.M., 2001. Meat yields in the introduced freshwater crayfish, Pacifastacus leniusculus (Dana) and Astacus leptodactylus Eschscholtz from British waters. Aquaculture Research, 32, 421-417.

HARSÁNYI T., ROGOVSZKY Z., 1996. Fogadj örökbe egy patakot! 4: Rákfelmérés. Kutatástervezés és adatfeldogozás (Adopt a stream! 4: Crayfish monitoring. Research plan and data processing). Fiatalok Természetismereti Klubja and Göncöl Alapítvány, Budapest, Vác, 108 p.

HERBORG L.M., RUSHTON S.P., CLARE A.S., BENTLEY M.G., 2003. Spread of the Chinese mitten crab (Eriocheir sinensis H. Milne Edwards) in Continental Europe: analysis of a historical data set. Hydrobiologia, 503, 21-28. 
HOLDICH D.M., 1999. The negative effects of established crayfish introductions. In Gherardi, F., HOLDICH, D. M. (Eds) Crayfish in Europe as alien species. How to make the best of a bad situation? A. A. Balkema, Rotterdam and Brookfield, 3147.

HOLDICH D.M., PÖCKL M., 2005. Does legislation work in protecting vulnerable species? In: FÜREDER L. and SOUTY-GROSSET C., 2005: European native crayfish in relation to land-use and habitat deterioration with a special focus on Austropotamobius torrentium, CRAYNET, Volume 3, Bull. Fr. Pêche Piscic., 376-377, 809-828.

HUDEC I., 2001. Cerveny (Ekosozologicky) zoznam korovcov (Crustacea) Slovenska. In: BALÁZ D., MARHOLD K., URBAN P. (eds). Cerveny zoznam rastlin a zivicichov Slovenska. Ochrana prirody, 20, Supplement, 87-90.

ILLÉS P., 2002. A jelzõrák (Pacifastacus leniusculus) elõfordulása Magyarországon. Cinege, 7, 39-41.

ILLÉS P., 2004a. Adatok a kövi rák (Austropotamobius torrentium SCHRANK 1803) elõfordulásához és biológiájához a Kõszegi-hegységben. Állattani Közlemények (in press).

ILLÉS P., 2004b. A jelzõrák (Pacifastacus leniusculus DANA 1852) elõfordulása Magyarországon. Állattani Közlemények (in press).

INGLE R.W., 1986. The Chinese mitten crab Eriocheir sinensis a continuous immigrant. The London Naturalist, 65, 101-105.

IUCN, 2003. IUCN 2003 Red List of Threatened Species. IUCN, Gland, Switzerland.

JIN G., LI Z., XIE P., 2001. The growth pattern of juvenile and precocious Chinese mitten crabs Eriocheir sinensis (Decapoda: Grapsidae), stocked in freshwater lakes if China. Crustaceana, 74, 261-273.

KISZELY P., 1992. ASTACUS’92. A Balaton és a Bakony rákállományának kutatása. Research Report, p. 41.

KISZELY P., 1994. ASTACUS’94. A Balaton és a Bakony rákállományának kutatása. Research Report, p. 29.

KONTSCHÁN J., 2001. Adatok Majk (Észak-Vértes) magasabbrendû rák (Crustacea: Amphipoda et Isopoda et Decapoda) faunájához. Folia Historico Naturalia Musei Matraensis, 25, 65-68.

KOVÁCS T., AMBRUS A., 1998-99. Eurylophella karelica TIENSUU 1935 in the Carpathian Basin (Ephemeroptera: Ephemerellidae). Folia Historico Naturalia Musei Matraensis, 23, 153-156.

KOVÁCS T., AMBRUS A., 2001. Ephemeroptera, Odonata and Plecoptera larvae from the rivers of Rába and Lapincs (Hungary). Folia Historico Naturalia Musei Matraensis, $25,145-162$.

LANSZKY J., MOLNÁR T., 2003. Diet of otters living in three different habitats in Hungary. Folia Zoologica, 52, 378-388.

LEGE NR. 462., 2001. Pentru aprobarea Ordonan ei de urgen a Guvernului nr. 236/2000 privind regimul ariilor naturale protejate, conservarea habitatelor naturale, a florei $i$ faunei s Ibatice. Publicat in Monitorul Oficial, Partea I, nr. 433.

LIGHT T., 2003. Success and failure in a lotic crayfish invasion: the roles of hydrologic variability and habitat alteration. Freshwater Biology, 48, 1886-1897.

MAGUIRE I., GOTTSTEIN-MATOCEC S., 2004. The distribution pattern of freshwater crayfish in Croatia. Crustaceana, 77, 25-47. 
NESEMANN H., PÖCKL M., WITTMANN K.J., 1995. Distribution of epigean Malacostraca in the middle and upper Danube (Hungary, Austria, Germany). Miscellanea Zoologica Hungarica, 10, 49-68.

PAUNOVIC M., CAKIC P., HEGEDIS A., KOLAREVIC J., LENHARDT M., 2004. A report of Eriocheir sinensis ( $\mathrm{H}$. Milne Edwards, 1854) [Crustacea: Brachyura: Grapsidae] from the Serbian part of the Danube River. Hydrobiologia, 529, 275-277.

PINTÉR K., THURÁNSZKY M., 1983. A ráktermelés fejlesztésének lehetõségei Magyarországon. Halászat, 76, 3-6.

PUKY M., 2000. Distribution of Decapoda species along the Hungarian Danube section and some tributaries with special emphasis on their conservation status. Limnological Reports, 33, 285-290.

PUKY M., 2004. Zoological mapping along the Hungarian lower Danube: Importance, aims and necessity discussed with the example of tree unrelated groups, Decapoda, Amhibia and Reptilia. Limnological Reports, 35, 613-618.

RABITCH W., SCHIEMER F., 2003. Chinesische Wollhandkrabbe (Eriocheir sinensis) in der österreichischen Donau festgestellt. Österreichischs Fischerei, 56, 61-65.

RALLO A., GARCIA-ARBERAS L., 2002. Differences in abiotic water conditions between fluvial reaches and crayfish fauna in some northern rivers of the lberian Peninsula. Aquatic Living Resources, 15, 119-128.

RETTIG K., 2000. Auffindung ven Wirbeltier-Strassenverkehrsopfern bei meinen Radtouren in Ostfriesland im Zeitraum 1996-2000. Beitraege zur Vogel- und Insectenwelt Ostfieslands, 154, 2-4.

ROGOVSZKY Z., 1995. Marad-e esélye a kövi ráknak? Élet és Tudomány, 48, 1059-1061.

ROGOVSZKY Z., 2004. A Fiatalok Természetismereti Klubja kövi rák- (Austropotamobius torrentium) állomány felméréseinek eredményei a Börzsöny és a Visegrádi-hegység területén 1990-2001. között. Állattani Közlemények (in press).

SALLAI Z., PUKY M., 1998. A „Nimfea” természetvédelmi Egyesület Halfaunisztikai Munkacsoportjának rák-(Decapoda), kétéltû- (Amphibia) és hüllõ- (Reptilia) faunisztikai adatai. A Puszta, 15, 137-154.

SERBAKA M.N., 1994. Tservona Kniga Ukraini. Travinnij Svit. Ukrainska Encyclopedia. Kiev. Ukraine, $440 \mathrm{p}$.

SAENZ D., JOHNSON J.B., ADAMS C.K., DAYTON G.H., 2003. Accelerated hatching of Southern leopard frogs (Rana spenocephala) eggs in response to the presence of a crayfish (Procambarus nigricinctus) predator. Copeia, 3, 646-649.

SCHULZ R., SMIETANA P., 2001. Occurrence of native and introduced crayfish in northeastern Germany and northwestern Poland. Bull. Fr. Pêche Piscic., 361, 629641.

SIDOROVICH V.E., MACDONALD D.W., PIKULIK M.M., KRUUK H., 2001. Individual feeding specialization in the European mink, Mustela lutreola and the American mink, M. vison in north-eastern Belarus. Folia Zoologica, 50, 27-42.

STATZNER B., PELTRET O., TOMANOVA S., 2003. Crayfish as geomorphic agents and ecosystem engineers: effect of a biomass gradient on baseflow and flood-induced transport of gravel and sand in experimental streams. Freshwater Biology, 48, 147163.

STENROTH P., NYSTRÖM P., 2003. Exotic crayfish in a brown water stream: effects on juvenile trout, invertebrates and algae. Freshwater Biology, 48, 466-475. 
STUCKI T., ROMER J., 2001. Will Astacus leptodactylus displace Astacus astacus and Austropotamobius torrentium in Lake Ageri, Switzerland? Aquatic Sciences, 63, 477-489.

THURÁNSZKY Z., 1960. A ráktelepítésrõl se feledkezzünk meg! Halászat, 7, 37.

THURÁNSZKY M., FORRÓ L., 1987. Data on distribution of freshwater crayfish (Decapoda: Astacidae) in Hungary in the late 1950s. Miscellanea Zoologica Hungarica, 4, 6569.

TRIEBSKORN R., ADAM S., CASPER H., HONNEN W., PAWERT M., SCHRAMM M., SCHWAIGER J., KÖHLER H.R., 2002. Biomarkers as diagnostic tools for evaluating effects of unknown past water quality conditions on stream organisms. Ecotoxicology, 11, 451-465.

VORBURGER C., RIBI G., 1999. Aggression and competition for shelter between a native and an introduced crayfish in Europe. Freshwater Biology, 42, 111-119.

VYHLASKA 395/1992., 1992. Kterou se provadeji nektera ustanoveni zakona CNR c. 114/1992 Sb. o ochrane prirody a krajiny. Prilohy III. MZP CR.

WESTMAN K., SAVOLAINEN R., JULKUNEN M., 2002. Replacement of the native crayfish Astacus astacus by the introduced species Pacifastacus leniusculus in a small, enclosed Finnish lake: a 30-year study. Ecography, 25, 53-73.

ZIMMERMANN W., 1993. Rote Liste der Flusskrebse (Decapoda: Astacidae) Thüringens. In: FRITZLAR, A., STREMKE, A., KROPIK, C. (eds), Naturschutzreport. Rote Listen ausgewahlter Pflanzen- und Tierartengruppen sowie Pflanzengesellschaften des Landes Thüringen, 5, 53-54.

13/2001, 2001. A védett és fokozottan védett növény- és állatfajokról, a fokozottan védett barlangok körérõl, valamint az Európai Közösségben természetvédelmi szempontból jelentõs növény- és állatfajok közzétételérõl. A környezetvédelmi miniszter 13/2001. (V. 9.) KöM rendelete. Magyar Közlöny, 53, 3446-3511.

30/1994, 1994. Zakon o zaštiti prirode. Narodne Novine.

46/2004, 2004. Uredba o prostozivecih zivalskih vrstah. Uradni list Republike Slovenije.

50/93, 1993. Regulation of protection natural rareness. Sluzbeni Glasnik Republike Srbije.

76/1998, 1998. Pravilnik o zaštiti rijecnih rakova. Narodne Novine.

82/2002, 2002. Pravilnik o uvrstitvi ogrozenih rastlinskih in zivalskih vrst v rdeci seznam. Uradni list Republike Slovenije. 